\title{
Indonesia and The Criminalization of Illegal, Unregulated, and Unreported Fishing at the Global Level
}

\author{
Irfan Ardhani \\ Department of International Relations, Faculty of Social and Political Sciences, Universitas Gadjah Mada, Indonesia \\ muhammad.irfan.ardhani@ugm.ac.id \\ Submitted: 23 November 2020; Revised: 13 February 2021; Accepted: 22 February 2021
}

\begin{abstract}
Abstrak
Sikap tegas yang diambil oleh Pemerintahan Presiden Joko Widodo dalam memerangi Illegal, Unreported, and Unregulated (IUU) Fishing telah menarik perhatian yang luas dari akademisi. Namun demikian, riset yang ada cenderung fokus untuk menganalisis penegakan hukum dalam bentuk kebijakan penenggalaman kapal. Konsekuensinya, studi yang ada tidak mampu memahami bagaimana di saat yang bersamaan Indonesia mengatasi persoalan tersebut dengan mengkriminalisasi IUU Fishing di level global. Tulisan ini bertujuan menutup celah tersebut. Memanfaatkan lima tahapan dalam evolusi historis pembentukan rezim pelarangan global yang diperkenalkan oleh Andreas dan Nadelmann (2006), tulisan ini mengivestigasi perkembangan kampanye yang dilakukan oleh Indonesia untuk mengkriminalisasi IUU Fishing dan mengidentifikasi sejumlah hambatan yang dihadapi oleh Indonesia dalam mendorong kemajuan kampanye kriminalisasi tersebut. Tulisan ini menemukan bahwa Indonesia tengah berada di tahapan ketiga pembentukan rezim pelarangan global terhadap kejahatan transnasional terorganisir di industri perikanan dan harus menghadapi hambatan berupa lemahnya argumentasi dan ketidaksepakatan sejumlah negara.

Kata kunci: kriminalisasi, IUU Fishing, kejahatan transnasional terorganisir, kejahatan perikanan transnasional terorganisir.
\end{abstract}

\begin{abstract}
The staunch measures taken by President Joko Widodo's administration in combating Illegal, Unreported, and Unregulated (IUU) Fishing has attracted considerable attention from academia. However, previous studies focused on analyzing law enforcement measures in terms of the sinking-vessel policy. Consequently, they failed to adequately comprehend how Indonesia deals with the problem by criminalizing IUU Fishing at the global level. This article attempts to fill such a gap. Employing the five stages of the historical evolution of a global prohibition regime, introduced by Andreas and Nadelmann (2006), this research investigated the progress of Indonesia's campaign to criminalize IUU Fishing at the global level and identified some hurdles that Indonesia has to address in fostering the advancement of the criminalization campaign. This article discovered that Indonesia has arrived at the third stage of making the global prohibition regime of transnational organized crime in the fisheries industry and has to deal with the hurdles of argumentation weakness and disagreement from several countries.

Keywords: criminalization, IUU Fishing, transnational organized crime, transnational organized fisheries crime.
\end{abstract}

\section{INTRODUCTION}

Indonesia is the largest archipelagic country in the world with valuable fisheries assets. This country is not only endowed with one of the highest marine biodiversity but also one of the most fertile fishing grounds in the world (Conway, 2018). Unfortunately, Indonesia has not been able to protect and manage its fisheries sector in an effective manner. The decades of the rampant practices of IUU Fishing committed by foreign fishing vessels have made the country unable to attain the maximum economic potential of its fisheries industry. The Ministry of Marine Affairs and Fisheries (MMAF) estimated that the IUU Fishing in Indonesian water has caused between USD 3 and 20 billion losses per year (Conway, 2018). Notwithstanding the sheer scale of its economic loss and socio-ecological impacts, the government has never taken adequate measures to curb IUU Fishing in its ocean (Sutinen, 2013). 
After President Joko Widodo came to power, Indonesia has increased its attempt to combat IUU Fishing. During his first tenure, President Widodo attempted to embrace the sea and turn Indonesia into a global maritime fulcrum (Connelly, 2015; Sukma, 2014). Concerning the fisheries industry, this grand vision is strengthened by putting the sector as one of the priorities in Indonesia's short-term development agenda (Bappenas, 2015). Furthermore, President Widodo manifests its vision through the increase in institutional support by establishing the Coordinating Ministry of Maritime and Investment Affairs (CMMIA) and doubling the budget of MMAF (Scarpello, 2020). In addition, President Widodo's commitment to reform Indonesia's fisheries sector was evident in his appointment of Susi Pudjiastuti as the Minister of Marine Affairs and Fisheries. With her experience as a seafood businesswoman who suffered a loss due to illegal fishing, Susi had intensified the law enforcement measure by sinking hundreds of foreign fishing vessels committed to IUU Fishing in Indonesia's waters. This article seeks to understand Indonesia's policy to combat IUU Fishing under President Jokowi's administration. In particular, this article pays attention to the increase in Indonesia's engagement with the international government network to criminalize IUU Fishing by garnering support to categorize IUU Fishing as Transnational Organized Crimes (TOC).

Indonesia's tough stance to combat IUU Fishing has attracted considerable interest from academia. They investigated the national and international legal framework according to the government's effort to enforce its law to combat the practice (Kristiyanto, 2015; Busro, 2017). In this regard, (Liliansa, 2020b) examined that the sinking and burning of foreign fishing vessels committed to IUU Fishing were necessary under the UNCLOS framework, and she suggested a market-based approach to combat IUU Fishing (Liliansa, 2020a). Liliansa's (2020a) research shows that Indonesia's external engagement with other countries is the key to effectively eradicating IUU Fishing, which lacks attention from the observers of Susi's unconventional policy. Despite this little attention, Taufik (2017) and Chapsos
\& Hamilton (2018) have raised concern about Susi's campaign to categorize IUU Fishing as TOC to the international society. However, these researchers have paid no attention to figure out the progress of the campaign. This article fills such gaps.

The problems analyzed in this article are twofold. First, this research attempts to locate the progress of Indonesia's external engagement with the international government network to criminalize IUU Fishing as TOC. Second, this research tries to identify some hurdles that Indonesia has to face during the criminalization campaign.

To answer the research problems, this article employed Andreas and Nadelmann's (2006) five stages of the historical evolution of a global prohibition regime. This article revealed that Indonesia has arrived at the third stage of making the global prohibition regime of TOC in the fisheries industry. In this stage, Indonesia has been highly active in various international forums to convince international society to criminalize IUU Fishing. Pushing forward the criminalization to the highest level of the global prohibition regime would be an arduous process. That said, Indonesia has to strengthen its criminalization arguments and develop various strategies to make the opposing countries support the criminalization of IUU Fishing.

\section{LITERATURE REVIEW}

This section identifies several studies discussing Indonesia's effort in combating IUU Fishing. In general, the topic has become a subject of inquiry from two disciplines in social science, including law and International Relations (IR). Insofar, analysis on the MMAF-led sinking-vessel policy has attracted considerable interest from legal and IR scholars. Focusing investigation on that domestic law enforcement measure, indeed, is only half of the story. Contrary to the research on domestic law enforcement, there has been little discussion about how Indonesia deals with IUU Fishing at the regional and international levels. While some scholars have embarked on such an analysis, their analysis frameworks are insufficient to comprehend how Indonesia tries to control IUU Fishing through criminalization at the regional and international level. 
Legal analysis on Indonesia's stringent measures to curb IUU Fishing put primary concern on finding the justification of burning and sinking vessels caught fishing in Indonesia's waters without possessing a license by referring to the domestic and international law. Despite all questions on the legality of such measures, some scholars remind that article 69 (4) of Law No. 45/2009 on Fisheries provides a legal basis for the policy to burn and sink illegal fishing vessels (Ikrami, 2017). Every sinking of illegal fishing vessels by Indonesia's authority is justifiable because it fulfills some steps and conditions mandated by the law (Busro, 2017). In addition, such stringent measures are not in contravention of international law since UNCLOS, the most comprehensive convention governing the sea, paves the way for every state party to take necessary action in ensuring legal compliance within their EEZ (Liliansa, 2020b). Be that as it may, some researchers also raised concern on the possibility of contradiction between the stern measure and international law. Since the UNCLOS has not incorporated burning and sinking the vessels as a law enforcement measure in EEZ (Rustam, 2014), how Indonesia's inform the flag states regarding the detain of their Fishing masters and crews may contravene the Vienna Convention on Consular Relations of 1993 (Busro, 2017).

International Relations analysis has emphasized the reasons behind the sinking and burning of illegal fishing vessels. In this regard, domestic politics dynamics provide an avenue for the more assertive approach in Indonesia's external relations. The uncommon measure can be comprehended as coercive diplomacy (Rijal, 2019) to carry out the global maritime fulcrum vision of the president. The coercive measure to sink the illegal fishing vessels, affecting many neighboring countries, can also be comprehended as an effort to reassert the state's authority (Connelly, 2015) and satisfy the increasing nationalist sentiment among Indonesians (McRae, 2019). This rising nationalism in Indonesia is regarded as a determining factor of the enormous support from the people for such policy. Isnurhadi (2018) went one step further by investigating how the government garnered popular support in sinking the illegal fishing vessels through the lens of securitization. The framing of the problem from a security angle, in turn, enables the employment of an extraordinary action to combat IUU Fishing.

In this respect, it is essential to bear in mind that the studies mentioned above do not consider the increase in Indonesia's government engagement with the international government network to curb IUU Fishing at the regional and global levels. Such analyses have overlooked how the Minister of Marine and Fisheries Affairs, Minister of Foreign Affairs, and Coordinating Minister of Maritime and Investment Affairs using several international forums such as regular session of Commission on Crime Prevention and Criminal Justice (CCPCJ), UN Ocean Conference, or ASEAN Regional Forum to garner international support and foster collective actions in combating IUU Fishing. The sinking of the vessel's policy may shed light on the assertive turn of Indonesia's government to combat IUU Fishing. However, such a deterrent measure would not be able to address the root cause of the problem. Indonesia's government realizes that IUU Fishing would only be eradicated if there is a concerted effort at the global level to take a new yet more stringent approach in dealing with the problem (Busro, 2019). Analysis of Indonesia's international campaign has become more critical. It is why research conducted by Taufik (2017) gives a clue to understand the bigger picture of Indonesia's effort in combating IUU Fishing. In his investigation on the rationale behind Indonesia's government campaign to categorize IUU Fishing as a Transnational Organized Crime (TOC), Taufik argued that the government has tried to seek a better result in eradicating IUU Fishing. Recognition of IUU Fishing as a TOC will increase the commitment of foreign countries to take a concrete step in fighting IUU Fishing and creating a more intensive international cooperation to deal with the pressing issue. In this regard, Chapsos and Hamilton (2018) and Hendarto (2018) justified Indonesia's campaign by developing the link between TOC and IUU Fishing in the case of Benjina.

Despite its contribution to open a further discussion on Indonesia's campaign to categorize IUU Fishing as a part of the TOC, such an analysis failed to discuss the 
complexity of Indonesia's strategy to garner international support in combating IUU Fishing. Another weakness in the previous studies is the failure to track the campaign's progress. Most of the studies regarding Indonesia and IUU Fishing have not attempted to comprehend what Indonesia has achieved and what obstacles Indonesia has to face in categorizing IUU Fishing as a TOC. This weakness is prevalent because of the limitations of the theoretical framework which the previous studies employed. Using a multidisciplinary approach by combining International Relations and legal analyses may shed new light on this endeavor. Concerning the complex and cross-border nature of IUU Fishing, Indonesia has been active in establishing bilateral and multilateral cooperation to frame the problem using the TOC lens (Busro, 2019).

Notwithstanding the enormous diplomatic effort that Indonesia took during the first period of President Jokowi's administration until today, international society has not reached a conclusion that IUU Fishing should be seen as a TOC problem. Even though some studies have emphasized the nexus between IUU Fishing and TOC, Indonesia's argumentation to frame IUU Fishing as TOC suffers many flaws to be accepted by international society (Stølsvik, 2019). Having realized the difficulty, the government has shifted its approach to the effort in regulating fisheries crime at the regional level (Rini, 2020). While the study on the government's effort to establish regional cooperation in combating crime related to fisheries may give us an optimistic view of the campaign's progress (Rini, 2020), the legal approach failed to locate the current stage of Indonesia's campaign. In addition, the lack of conceptual tools of the approach led the research to downplay some political aspects that might hinder the success of the campaign. Consequently, it failed to explain the limited progress of the campaign even after such a long effort and lame light that it had.

\section{THEORETICAL FRAMEWORK}

Having identified the paucity of previous research to comprehend Indonesia's fight against IUU Fishing at the international level, it was decided that the best approach to understand the campaign to categorize IUU Fishing as TOC is through the combination of International
Relations and criminology. Notwithstanding the increasing trans-governmental relations and international cooperation to control TOC, scant attention has been devoted to study the International Relations-criminology nexus (Loader \& Percy, 2012). By being attentive to cross-border criminalization and crime control phenomena, Andreas \& Nadelmann (2006) introduced a bridge between both disciplines that enable more detailed analysis on how states criminalize particular transnational activities.

In this paper, criminalization refers to a historical process in which certain activities and behaviors are justified and treated as criminal under the law (Farmer, 2016; McLaughlin \& Muncie, 2001). The creation of this new criminal activity is prevalent within the jurisdiction of a state and takes place across national borders. Given the growing attention of governments across the globe to a range of suspicious transnational activities, there has been an increase in the intensity of internationalization of crime control (Andreas \& Nadelmann, 2006). Using trans-governmental work and international organizations, some states try to convince others to criminalize such transnational activities.

Cooperation between states does not stop at criminalizing particular transnational activities. According to Andreas and Nadelmann (2006), several countries also work together to promote deeper and broader criminal justice control in identifying, dissuading, and prohibiting transnational crimes. To implement this international crime control, the task of institutions dealing with domestic crime control on a day-to-day basis, such as police, prosecutors, and courts, is extended. A set of rules and mechanisms are created to dictate their action and accommodate international law enforcement. Andreas and Nadelmann (2006: 255) suggested that such mechanisms may include 'extradition, bilateral and multilateral law enforcement treaties, international conventions, the criminal justice agencies of international organizations such as the United Nations and the international police organization (Interpol)'. Furthermore, several cooperatives to enforce the law carried out by regional and political networks also share the burden of making international crime control works. 
The international relations-criminology nexus introduced by Andreas and Nadelmann helps this research track Indonesia's campaign to criminalize IUU Fishing. For Andreas and Nadelmann, a successful attempt at criminalizing particular transnational activities will result in an international prohibition regime. The international prohibition regime is a favorable mechanism considering how current law enforcement measures at the unilateral and bilateral level lack effectiveness to deal with cross-border criminalized activities. Andreas and Nadelmann elaborated that the process of making international prohibition regimes consists of five stages. In the first stage, a transnational activity is not criminalized yet. It is still perceived as a legitimate activity that has state support to back its operation. However, in the second stage, the perception toward such activity witnesses change. Concerning states begin to redefine transnational activity as a problem and crime.

As a consequence, such transnational activity has to lose its legitimacy gradually. It is important to note that some states still turn a blind eye or even support such activity. In the third stage, proponents of the prohibition regime take a more active stance to convince international society so that the activity can be treated as a criminal. A global convention is the aim of the concerned states since it ensures the criminalized transnational activity status and entails a mechanism of law enforcement in international law structure. In the subsequent stage, the proponents of the regime rely on criminal laws and policing action to regulate the activity at the global level. In addition, international institutions and conventions coordinate the regulation. The fifth stage happens when the suppression of criminalized activity is successful, as indicated by the very low prevalence of the criminalized activities across the globe.

While the historical evolution of the international prohibition regime is useful to examine whether the criminalization is progressing or not, Andreas and Nadelmann also raised concern on several factors that might foster or hinder the making of such regime. By employing an analytically eclectic approach, both scholars combine three theoretical perspectives in IR (liberalism, realism, and constructivism) to make sense of the internationalization of crime control. The combination of three perspectives has shed light on the complex links between interests, power, and norms that influence the dynamics of effort to establish an international prohibition regime. Liberalism helps us understand that the proliferation of international police cooperation fostered by interdependency between states has led to common interests in responding to the growing transnational activities. On the other hand, realism, emphasizing the primacy of power politics, sheds light on how powerful states shape the design of the regime. Constructivism is then useful to understand the redefinition of particular transnational activities as a crime by transnational moral entrepreneurs and how it evolved into a prohibition norm.

\section{RESEARCH METHOD}

This study is qualitative research with a case study method. According to Ragin (in Della Porta and Keating, 2008), the case study method is useful to scrutinize the formation of a case. The scrutiny can be done by doing a comprehensive empirical study on one or a limited number of phenomena. The case study method was chosen as it enabled this study to investigate the progress and the hurdles of Indonesia's campaign to criminalize IUU Fishing at the global level.

In collecting the data, this study used desk research and in-depth interview. Besides journal articles and books, the desk research data covered reports and official documents from government agencies, international organizations (IOs), and non-governmental organizations (NGOs). For instance, this research utilized the annual press briefing of the Ministry of Foreign Affairs, the 2020-2024 National Medium-Term Development Plan and Jakarta Concord. In addition, this study also analyzed data from various IOs, such as the report of the UN Ocean Conference and UNODC's official publication. Furthermore, this study also used reports from NGOs such as California Environmental Initiatives and Ocean Development Initiatives. Last but not least, this study also employed online news to collect statements from the government of Indonesia, foreign 
countries, and international organizations track the progress of Indonesia's campaign.

Realizing that some crucial data regarding Indonesia's campaign strategy were not covered in the literature, this study applied the in-depth interview to complete the needed information. The in-depth interview, conducted from August to September 2020, targeted public servants and NGO activists involved in the criminalization campaign. Interviewees comprised one former leading figure of Presidential Task Force to Combat IUU Fishing, one Indonesian Ambassador to a European country who was in charge of the campaign, two public servants from CMMIA, and one activist from Indonesia Ocean Justice Initiative.

\section{RESULT AND ANALYSIS}

\section{THE URGENCY TO CRIMINALIZE IUU FISHING}

The enormity of the fight against IUU Fishing during the first tenure of President Widodo has to be understood as a response toward political economy symptoms that he had to deal with. As the current account deficit had mounted because of the end of the global commodity boom, Indonesia had to find a new source of export. As the largest archipelagic country in the world and the second-largest producer of seafood after China, Indonesia has the potential to increase its revenue from the wild fisheries capture industry. However, illegal fishing committed primarily by foreign fishing vessels and unsustainable fishing conducted by domestic vessels led to the country's inability to reach the economic potential of its fisheries industry (KKP 2015). IUU Fishing has been estimated to cost between USD 3 and 20 billion each year in Indonesia (Conway 2018). Moreover, the Minister of Marine Affairs and Fisheries, Susi Pudjiastuti, said that Indonesia lost about IDR 209.1 billion of tax revenue from 187 taxpayers in the fisheries industry in 2016 (Tempo, 2016). The decade of intensive IUU Fishing in Indonesian waters has led to a sharp decline in the number of the fisheries household of this largest archipelagic nation in the world. While in 2003, the fisheries household in Indonesia reached 1.6 million households, in 2013, the number of the fisheries household declined almost half of it to only 800 thousand (Hamdani, 2018).
Thus, to ensure the prosperity of its society from the fisheries sector, Indonesia had to curb IUU Fishing whatever it takes. It came as no surprise, then, that fulfillment of the sovereignty pillar was the policy priority of MMAF under the leadership of Minister Susi. The fulfillment of this sovereignty pillar has been done by invoking Article 69 section (4) in Indonesia's Fisheries Law. This article has enabled the government to burn or sink fishing vessels committed to IUU Fishing in Indonesia's waters. The law enforcement measures have been considered extraordinary measures by many observers because of their massive scale and media exposure (Taufika, 2020). It seems that the burning and sinking vessels policy has led to a significant decline in the practices of IUU Fishing in Indonesian waters (Tempo, 2017). As MMAF had succeeded in reducing the number of IUU Fishing in Indonesia's sea, it paved the way for sustainable marine and fisheries resources and a prosperous fisheries industry in Indonesia.

Although Indonesia's Fisheries Law provides an opportunity for the government to take a staunch measure to deter future perpetrators of IUU Fishing, relying only on unilateral measures will not make Indonesia tackle the root causes of the problem. After finishing the analysis and evaluation of ex-foreign fishing vessels that operated in Indonesia's waters, Susi and her team concluded that IUU Fishing practices in Indonesia contained the element of TOC (Interview, October 2020). These foreign fishing vessels were operated by foreign companies establishing front companies and fabricating the handover of document of ownership; performing double-flagging and double-registering of vessels; manipulating the report to avoid monitoring and taxes; using local names to take the benefit from Indonesia's fuel subsidy and smuggle it; sailing without port and seaworthiness clearance; deactivating Vessel Monitoring Systems and Automatic Identification Systems; employing foreign captains and crews against Indonesian laws; using illegal fishing gears; transshipment at sea; and fabricating fishing authorization and encroach in waters reserved for local, small-scale fisher (Scarpello 2020). In light of the evidence, Pudjiastuti (2020) realized that the only way to eliminate IUU Fishing was by 
redefining the problem as a TOC and ensuring that other countries comprehend the problem from a similar perspective to take global collective action against it.

Indonesia's effort to criminalize IUU Fishing has a grounding in the academic discourse. In this regard, several publications identified the nexus between IUU Fishing and TOC. Chapsos and Hamilton (2018) argued that IUU Fishing enables perfect transnational organized crime conditions in the fisheries sector to thrive. In this regard, organized crime groups with a long experience conducting their transnational criminal activities perceived that IUU Fishing could cover their illicit business (Liddick, 2014). It came as no surprise that several researchers found that a range of transnational organized crimes like corruption, tax crime, money laundering, drug trafficking, and smuggling (including migrant, fuel, weapons, and endangered species) was prevalent in IUU Fishing (De Coning, 2011; Percy, 2016).

The criminalization of IUU Fishing is considered a way to achieve a more effective result in the fight against IUU Fishing. It is important to note that the perpetrators share a common perception that IUU Fishing is a low-risk activity (Lindley et al., 2019). The possibility of such perception to prevail is related to the effectiveness of current measures in dealing with it. Rather than seeing the criminal lens problem, current measures perceive IUU Fishing as a fisheries management problem (Lindley et al., 2019; Telesetsky 2014; UN Ocean Conference 2020). As a consequence, the problem of transnational organized crimes is prolonged without enough punishment.

Furthermore, the absence of governance capable of dealing with fisheries, including transnational organized crimes, comprehensively aggravates the situation (Lindley et al., 2019). Former Deputy of Maritime Sovereignty of Indonesia's Ministry of Maritime and Investment Affairs, Arif Havas Oegroseno (2019), once said that "The FAO will likely say that crimes are not within its mandate and the UNODC may argue that fisheries are not their responsibilities. Interpol can liaise, but it is not an international organization with a mandate to create global norms to be implemented globally." Thus, the stakeholders in transnational organized fisheries crimes, such as port states, coastal states, and flag states and fisheries, must establish an international law instrument that can deter and reduce fisheries crimes (UN Ocean Conference, 2020).

The finding of the Benjina case has opened a window of opportunity for Indonesia to push the agenda of international crime control on IUU Fishing. The widespread attention from international media and academia has generated a sense of the severity of the IUU Fishing problem. The Benjina case has demonstrated how IUU Fishing might contain the traditional TOC prohibited by the international society for a long time. In the Benjina case, the migrant Fishing crews from several Southeast Asian countries such as Myanmar, Cambodia, and Laos had to deal with human rights abuse after entering the fisheries industry. Working for Pusaka Benjina Resources, these migrant fishermen testified to Indonesian court that they witnessed the torture and working restlessly, sometimes up to 24 hours, without receiving any payment (The Guardian 2016). They added that the company incarcerated these fishermen in cells. In a report to Associated Press, McDowell, Mason, and Mendoza (2015), it was claimed that what happened in Benjina was slavery. This perception, then, created a sense of urgency among Indonesia's policymakers to foster the criminalization of IUU Fishing.

\section{Indonesia's Campaign to Criminalize IUU Fishing: Progress and Hurdles}

Indonesia has started the international campaign to criminalize IUU Fishing long before Joko Widodo became the President of Indonesia. Having succeeded in fostering UN ECOSOC to officially recognize illegal logging as one of the transnational organized crimes, the Indonesian Ministry of Foreign Affairs, under the leadership of Hassan Wirajuda, has embarked on a series of a diplomatic effort to make the $\mathrm{UN}$ issued a resolution recognizing IUU Fishing as a new emerging form of transnational crime (Wirajuda, 2009). In the fourth session of the conference of the parties to the United Nations Convention against Transnational Organized Crime (UNTOC COP), the Head of Indonesia's 
delegation, H.E. Triyono Wibowo, raised concern on the nexus between IUU Fishing and TOC. Based on articles 2 and 3 in the convention, Triyono claimed that criminal activities found in IUU Fishing are in accordance with the criteria of transnational organized crimes (UNTOC, 2008). With that being said, Triyono and Indonesia's delegation tried to redefine the IUU Fishing and convince the conference to criminalize such practice.

Even though it had kicked off the campaign, the criminalization of IUU Fishing had never become a priority of the diplomatic establishment under Yudhoyono's administration. During his presidency, Yudhoyono focused on middle power diplomacy to restore Indonesia's reputation and stand on the world stage by building a bridge between the western and Islamic world (Alvian et al., 2017; Fitriani 2015).

After Jokowi came to power in 2014, there was a significant shift in Indonesia's foreign policy agenda. Considered as an inward-looking president by numerous commentators (David and Harris-Rimmer, 2016; Harding and Mechant, 2016; Qin, 2015), Jokowi did not withdraw Indonesia from its active role in various multilateral forums. Alvian et al. (2017) suggested that Jokowi's administration shows a different foreign relations approach by adopting a meta-power strategy while leaving Yudhoyono's relational power strategy behind. Jokowi may be regarded as a leader who retreats Indonesia's leadership in several multilateral forums such as ASEAN and the UN (Purba, 2019; Qin, 2015). However, under the Global Maritime Fulcrum vision banner, President Jokowi increased Indonesia's effort at the global level to promote alternative normality in combating IUU Fishing (Alvian et al., 2017). Indonesia's effort to establish a global prohibition regime on IUU Fishing, then, can be seen as a translation of this strategy. Indonesia's campaign to criminalize IUU FISHING during Jokowi's first term in office was quite intensive. While under Yudhoyono's presidency, the role in criminalizing IUU Fishing was dominated by the Ministry of Foreign Affairs, in Jokowi's administration, other institutions such as the Ministry of Marine Affairs and Fisheries as well as Coordinating Ministry on Maritime and Investment Affairs (CMMIA) have joined the fray (Interview, September 2020a; Interview, September 2020b; Interview, October 2020). Each institution involved in the campaign has the responsibility to redefine the IUU Fishing problem as TOC and follow up the redefinition by an international legal mechanism to institutionalize the criminalization. The combination of these three institutions has led to a more varied approach in achieving the targets mentioned above. On the one hand, the MMAF emphasized bilateral and international engagement to garner criminalization support (Interview, October 2020). On the other hand, the Coordinating Ministry of Maritime and Investment Affairs focused its engagement at the regional level (Interview, September 2020a; Interview, September 2020b). While both ministries implemented a different strategy, the Ministry of Foreign Affairs always assisted in the effort of both institutions.

At the bilateral level, Norway has been the strategic partner of Indonesia to criminalize IUU Fishing. Letter of Intent on Marine Affairs and Fisheries Cooperation of the Indonesia Ministry of Marine Affairs and the Ministry of Trade, Industry, and Fisheries of the Kingdom of Norway signed in 2015 laid the foundation for such cooperation. In this Letter of Intent, Indonesia and Norway declared their commitment to work hand in hand by supporting each other in their effort to combat the transnational organized fisheries crime (TOFC) in international forums. The Letter of Intent was followed up by conducting several join events to raise awareness and understanding about the seriousness of TOFC, the High-Level Side Event of Transnational Organized Fisheries Crime (TOFC) in the 25th session of the CCPCJ in 2016 (Asydhad, 2016a). In addition, both countries have shown continuing support to the International Symposium on Fisheries Crimes.

At the international level, Indonesia has used some multi-stakeholder forums and the UN System to criminalize IUU Fishing. Indonesia utilized the opportunity in multi-stakeholder forums, which involved the participation of state and non-state actors such as the International Symposium on Fisheries Crime and Our Ocean Conference to redefine the problem of IUU Fishing. Indonesia became the convener of the second 
symposium in 2016. In the symposium, Indonesia mainly aimed to increase participants' comprehension of fisheries crime and why it should be categorized as TOC. Susi asserted that position in her opening speech of the symposium by stating that Indonesia fully supports the notion to categorize fisheries crime as TOC and persuading UNODC to officially announce the categorization (Detik, 2016). Besides the International Symposium on Fisheries Crime in 2016, Indonesia also hosted Our Ocean Conference in 2018. Indonesia did not waste its opportunity to redefine the IUU Fishing problem as TOC. In that conference, Indonesia's Presidential Task Force to Combat IUU Fishing (Satgas 115) held a side meeting discussing the urgency and strategy to combat TOFC.

The UN System is the main arena for Indonesia to create a regime criminalizing IUU Fishing. Indonesia has tried to seek acknowledgment and resolution from UN Bodies to further the process of criminalization. In the 25th session of the CCPCJ, Susi Pudjiastuti, who acted as Indonesia's Head of Delegation, raised concern on TOFC as one of the emerging transnational organized crimes. Susi claimed that TOFC not only threatened Indonesia, the largest archipelagic country endowed with the several most fertile fishing grounds in the world, but also other countries. Susi supported her claim with a set of evidence of the conventional transnational organized crimes in the fisheries industry. However, as Susi expressed her regret, other countries did not see similar weight problems as Indonesia had done. At the end of her speech, Susi hoped that other countries could join the march toward the categorization of TOFC as part of the TOC (Asydhad, 2016b). Believing that enough backing from other countries was at its disposal, Indonesia then used the first UN Ocean Conference in 2017 to seek a resolution from the UN General Assembly in institutionalizing the criminalization of IUU Fishing. In the partnership dialogue entitled "Making Fisheries Sustainable", Susi emphasized that the UN Members should create an independent team filled with experts to recommend the best institution to curb TOFC (Sulistiyono, 2017). Far more critical, Susi also encouraged the General Assembly to acknowledge such a proposal.
At the regional level, CMMIA has employed a different approach to criminalize IUU Fishing. Rather than devoting its time to redefine the problem of IUU Fishing as TOC, CMMIA pays particular attention to create an international legal instrument as the basis to criminalize IUU Fishing. While MMAF has utilized the existing forums in its criminalization effort, CMMIA has attempted to establish a new instrument in dealing with IUU Fishing and its related crimes. This effort was started when CMMIA held a 'Regional Conference to Establish a Regional Convention Against IUU Fishing and Its Related Crimes' in Bali, 2016. This conference was attended by ASEAN member states, Indonesia's neighboring countries in the region such as Australia, New Zealand, Timor Leste, Papua New Guinea, China as well as seafood market countries such as Japan, European Union, the United States, and South Korea (Rini, 2020). International Organizations sharing similar concerns in addressing IUU Fishing, such as FAO, UNODC, and West Africa SFRC, also attended the conference (Rini, 2020).

Considering the forum dynamics, CMMIA's effort to establish the regional convention has witnessed several adjustments. Following a suggestion from the 1st Technical Expert Meeting of the conference in 2017, CMMIA changed the forum's name to Regional Conference on the Establishment of a Regional Cooperation Agreement against Crimes Related to Fisheries. By the end of 2020, the forum has finished its 1st Technical Working Group in 2018, which discussed the cooperation agreement framework (Interview, September 2020b). In fact, CMMIA had scheduled the 2nd Technical Working Group this year. However, because of the pandemic, the event should be canceled. CMMIA has been seeking the best time to reschedule the event.

Besides the CMMIA's initiative to make a legally binding regional agreement in addressing crime related to fisheries, Indonesia's Ministry of Foreign Affairs has advanced the IUU Fishing criminalization at the regional level through its engagement in IORA. Since being appointed as the Foreign Minister, Retno Marsudi has invested so much energy so that Indonesia can take the 
lead in IORA. Indonesia's leadership in IORA is one of the keys to implement the president's vision on Global Maritime Fulcrum (Weigold, 2015). As the Chair of IORA from 2015 to 2017, Indonesia has increased the level of the association by organizing the 1st IORA summit in 2017. At the end of the summit, the IORA member states issued Jakarta Concord 2017 to promote 'regional cooperation for a peaceful, stable and prosperous Indian Ocean' (IORA, 2017).

Evaluating the progress of Indonesia's campaign to criminalize IUU Fishing through Andreas and Nadelmann's framework on the historical evolution of the global prohibition regime, it is safe to say that Indonesia has arrived at the third stage of such regime. Indonesia and its counterparts-concerning countries like Norway and transnational moral entrepreneurs on combating IUU Fishing such as PESCAdolus-have been able to redefine the TOC problem. Apart from the increase in international publication regarding the TOC aspect of IUU Fishing in member countries of the UN System as the target of Indonesia's campaign, the magnitude of the TOFC problem has been understood (Stølsvik, 2019). In addition, Indonesia and other parties involved in the International Symposium on Fisheries Crime successfully adopted the International Declaration on Transnational Organized Crime in the Global Fishing Industry or commonly referred to as Copenhagen Declaration. As of November 2020, 28 countries have signed the non-binding declaration.

Furthermore, IORA leaders have agreed to strengthen the regional cooperation in addressing crimes in the fisheries sector, as stated in the Jakarta Concord (IORA, 2017). Despite some notable achievements in redefining the magnitude of the problem of IUU Fishing by exploiting its TOC aspect, Indonesia's campaign at the international level has not been able to institutionalize the criminalization of IUU Fishing. In the 1st UN Ocean Conference 2017, Indonesia's delegation failed to get an official recognition to criminalize IUU Fishing until the end of the conference (Sulistiyanto, 2017). Furthermore, as of November 2020, the Regional Conference on the Establishment of a Regional Cooperation Agreement against Crimes Related to Fisheries has not reached any conclusion. In this research interview, some resource persons even showed their pessimism about the future of the conference on the change in the structural opportunity at the global and domestic levels to combat IUU Fishing (Interview, September 2020b).

Insofar, Indonesia has to deal with several obstacles in advancing the criminalization of IUU Fishing. First, Indonesia's argumentation to criminalize IUU Fishing has been criticized and sometimes rejected. Indonesia's campaign since 2008 has recurrently used the rhetoric to categorize IUU Fishing as TOC. Since the very beginning, some countries like Spain, China, Vietnam, and South Korea have cast their disagreement on that idea on the different regimes that regulate IUU Fishing and TOC (Rini, 2020). Furthermore, it cannot be denied that not all fishing vessels that have committed to IUU Fishing also performed forms of TOC at the same time.

Moreover, unreported and unregulated IUU Fishing elements are domestic and can be solved through domestic measures (Interview, September 2020a). Rather than having a positive impact on the progress of the campaign, that legal uncertainty in criminalizing IUU Fishing has hindered the process from concluding an international prohibition regime, Yuliantiningsih et al. (2018) suggested that the government should use the term of crimes in the fisheries sector, which has a basis in the international legal structure instead of categorizing IUU Fishing as TOC to achieve a better result of the campaign. Although she has used the term of transnational organized fisheries crime in many of her remarks, during her term in office, Susi Pudjiastuti, on many occasions, expressed her desire to put IUU Fishing and TOC at the same basket (Yuliantiningsih et al., 2018). On the contrary, recognizing this kind of rejection in the early phase of its self-initiated conference, CMMIA has made a fundamental adjustment by changing the conference name.

The second obstacle that Indonesia has to face is the limited strategy in its disposal to advance criminalization. According to Andreas \& Nadelmann (2006), the driver seat of several successful international crime control efforts has been filled by the powerful Western countries. They argued that the ability of a country like the US to 
combine its hard and soft power is fundamental in the criminalization of particular transnational activities such as the war against drugs and money laundering. For both scholars, the developing countries can only play second fiddle by organizing international crime control meetings, adjusting their criminal law to internationally agreed concepts, and ratified conventions that do not come from its initiative. In this light, Indonesia's initiative to criminalize IUU Fishing is a bold move. As a middle power country, Indonesia lacks the capability to coerce and co-opt other states to support its international crime control agenda. At the same time, Indonesia's effort to criminalize is not in line with the interest of China as a great power country. According to a report published by ODI (2020), China has a significant role in the global landscape of IUU Fishing. As the country with the largest distant water fishing fleets (DWF) worldwide, China has a huge involvement in prolonging IUU Fishing. The organization has identified that some vessels committed to IUU Fishing control the Chinese state-owned DWF company. It came as no surprise; then, on many occasions, China rejected Indonesia's initiative to criminalize IUU Fishing (Interview, October 2020) and showed its tendency to slow the progress of the conference (Interview, September 2020b).

\section{CONCLUSION}

The purpose of this study is to assess the progress of Indonesia's campaign to criminalize IUU Fishing at the global level. Employing the historical evolution of the global prohibition regime developed by Andreas and Nadelmann (2006), this study discovered that Indonesia has arrived at the third stage of making the global prohibition regime on TOC in the fisheries industry. This claim is based on the ability of Indonesia to redefine the pressing problem of IUU Fishing as a TOC. However, Indonesia has still been struggling to garner support for the establishment of an international convention that regulates the prohibition of TOC, which ubiquitously takes place in many IUU Fishing cases. Furthermore, several kinds of state-sponsored IUU Fishing in the landscape of the current global fisheries industry have become a stumbling block in advancing the formulation of such a global prohibition regime.

This study has added a new dimension to comprehend how Joko Widodo's government has tried to curb IUU Fishing. The previous studies have not dealt with Indonesia's effort to criminalize IUU Fishing at the regional and global levels in a satisfying manner. Most of the studies have focused on the law enforcement measure in terms of the sinking-vessel policy. Indeed, some researchers have devoted their time to develop a connection between IUU Fishing in Indonesia and TOC and embarked on analyzing how Indonesia deals with IUU Fishing at the regional and international levels. However, their analysis frameworks are insufficient to comprehend how Indonesia criminalizes TOC in fisheries industries at the regional and international levels. Andreas and Nadelmann's approach, which combines IR and criminology, has helped this study show a detailed analysis of the progress of the criminalization campaign significant for Indonesia in addressing one of the root causes of IUU Fishing.

The findings of this study suggest several courses of action for Indonesia to push the criminalization campaign forward. First, Indonesia has to strengthen its argument on how IUU Fishing can be categorized as a TOC. It can be done by enhancing support to the network of epistemic communities to formulate such an argumentation. Second, Indonesia must be able to diversify its strategy when dealing with opposing countries. If Indonesia can convince the opposing countries to support the criminalization, then it will be easier to establish the global prohibition regime on TOC in fisheries industries.

\section{ACKNOWLEDGMENT}

This article was supported by the research grant from the Department of International Relations, Faculty of Social and Political Sciences, Universitas Gadjah Mada 2020. Some data were gathered during the writer's master's degree at The University of Queensland, Australia. 


\section{REFERENCE}

Alvian, R. A., Putri, G. C., \& Ardhani, I. (2017). Haluan Baru Politik Luar Negeri Indonesia: Perbandingan Diplomasi 'Middle Power' Susilo Bambang Yudhoyono dan Joko Widodo. Jurnal Hubungan Internasional, 6(2). doi: 10.18196/hi.62112

Andreas, P., \& Nadelmann, E. A. (2006). Policing the globe: Criminalization and crime control in international relations. New York: Oxford University Press.

Asydhad, A. (2016, May 24). Banyak Negara yang Tertarik dengan Usulan Kejahatan Perikanan Sebagai TOC. Retrieved October 28, 2020, from Detiknews: https://news.detik.com/ber ita/d-3219459/banyak-negara-yang-tertarik-dengan-usu lan-kejahatan-perikanan-sebagai-toc

Asydhad, A. (2016, May 24). Menteri Susi Minta Dunia Internasional Serius Tangani Kejahatan Perikanan. Retrieved October 28, 2020, from Detiknews: https://news.de tik.com/berita/d-3216516/menteri-susi-minta-dunia-interna sional-serius-tangani-kejahatan-perikanan

Bappenas. (2015). Rencana Pembangunan Jangka Menengah Nasional (RPJMN). 2015-2019. Jakarta: Bappenas.

Busro, Z. M. (2019). Illegal, unreported and unregulated fishing and transnational organized fisheries crimes: Perspectives of legal and policy measures of Indonesia. (Doctoral Thesis). University of Wollongong.

Busro, Z. (2017). Burning and/or Sinking Foreign Fishing Vessels Conducting Illegal Fishing in Indonesia: Some Obligations and Loopholes. Asia-Pacific Journal of Ocean Law and Policy, 2(1), 174-179. doi: 10.1163/24519391-00201011

Chapsos, I., \& Hamilton, S. (2019). Illegal fishing and fisheries crime as a transnational organized crime in Indonesia. Trends in Organized Crime, 22(3), 255-273. doi: 10.1007/s12117-018-9329-8

Conway, S. (2018). Trends in Marine Resources and Fisheries Management in Indonesia; A 2018 Review. Retrieved March 17, 2020, from California Environmental Associates: https://www.packard.org/wp-content/uploads/2018/08/ Indonesia-Marine-Full-Report-08.07.2018.pdf.

Davies, M., \& Harris-Rimmer, S. (2016). Assessing Indonesia's Normative Influence: Wishful Thinking or Hidden Strength: Indonesia's normative influence. Asia \& the Pacific Policy Studies, 3(1), 83-91. doi: 10.1002/app5.119

De Coning, E. (2011). Transnational Organized Crime in the Fishing Industry: Focus On: Trafficking in Persons, Smuggling of Migrants, Illicit Drugs Trafficking. Retrieved September 19, 2020, from UNODC: https://www.unodc.org /documents/human-trafficking/Issue_Paper__TOC_in_the Fishing_Industry.pdf

Yuliantiningsih, A., Hartiwiningsih, H., Suherman, A. M., \& Latifah, E. L. (2018). From Illegal, Unreported and Unregulated Fishing to Transnational Organised Crime in Fishery from an Indonesian Perspective. Journal of East Asia and International Law, 11(2), 335-336. doi: 10.14330/ jeail.2018.11.2.04

Farmer, L. (2016). Making the modern criminal law: Criminalization and civil order (First edition). New York: Oxford University Press.

Harding, B. and Stefanie Merchant (2016), Indonesia's Inward
Turn. Retrieved October 10, 2020, from The Diplomat: https://thediplomat.com/2016/12/indonesias-inward-turn/ Hamdani, T. (2018, May 21). Susi Buka-bukaan Kerugian Akibat Pencurian Ikan. Retrieved October 26, 2020 from Detik.Com: https://finance.detik.com/berita-ekonomi -bisnis/d-4031053/susi-buka-bukaan-kerugian-akibat-pencu rian-ikan

Ikrami, H. (2017). Indonesia's Reform of Its Fisheries Law and Policy \& Cooperation with asean in Combating iuu Fishing. Asia-Pacific Journal of Ocean Law and Policy, 2(2), 318-330. doi: 10.1163/24519391-00202008

IORA. 2017. Jakarta Concord - The Indian Ocean Rim Association: Promoting Regional Cooperation for A Peaceful, Stable and Prosperous Indian Ocean. IORA. http://ditjenppi.kemendag. go.id/assets/files/publikasi/doc_20180626_jakartaconcord.pdf.

Kristiyanto, K. (2015). The Analysis of Foreign-Vessel Sinking as an Effort by The Government of Indonesia to Combat IUU Fishing Pursuant to International Law. Brawijaya Law Journal, 2(2), 69-83. doi: 10.21776/ub.blj.2015.002.02.04

L. Connelly, A., \& Research Fellow in the East Asia Program at the Lowy Institute for International Policy in Sydney. (2015). Sovereignty and the Sea: President Joko Widodo's Foreign Policy Challenges. Contemporary Southeast Asia, 37(1), 1-28. doi: 10.1355/cs37-1a

Liddick, D. (2014). The dimensions of a transnational crime problem: The case of IUU Fishing. Trends in Organized Crime, 17(4), 290-312. doi: 10.1007/s12117-014-9228-6

Liliansa, D. (2020a). Market-Based Measures Against Illegal, Unreported and Unregulated Fishing in Indonesian Waters. In M. C. Ribeiro, F. Loureiro Bastos, \& T. Henriksen (Eds.), Global Challenges and the Law of the Sea (pp. 121-143). Springer International Publishing. doi: 10.1007/978-3-030-42671-2_7

Liliansa, D. (2020b). The Necessity of Indonesia's Measures to Sink Vessels for IUU Fishing in the Exclusive Economic Zone. Asian Journal of International Law, 10(1), 125-157. doi: $10.1017 /$ S2044251319000183

Lindley, J., Percy, S., \& Techera, E. (2019). Illegal fishing and Australian security. Australian Journal of International Affairs, 73(1), 82-99. doi: $10.1080 / 10357718.2018 .1548561$

Loader, I., \& Percy, S. (2012). Bringing the 'outside' in and the 'inside' out: Crossing the criminology/IR divide. Global Crime, 13(4), 213-218. doi: 10.1080/17440572.2012.715402

Mawar Rini, A. (2020). Penguatan Upaya Penegakan Hukum "Kejahatan Terkait Dengan Perikanan" Melalui Regional Cooperation Agreement Against Crimes Related To Fisheries. Mimbar Hukum - Fakultas Hukum Universitas Gadjah Mada, 32(1), 106. doi: 10.22146/jmh.38280

McDowell, R., Mason, M., \& Mendoza, M. (2015, March 25) AP Investigation: Slaves may have caught the fish you bought. Retrieved August 29, 2020, from AP: https://www.ap.org/ explore/seafood-from-slaves/ap-investigation -slaves-may-have-caught-the-fish-you-bought.html

McLaughlin, E., \& Muncie, J. (Eds.). (2001). The Sage dictionary of criminology. London: SAGE.

McRae, D. (2019). Indonesia's South China Sea Diplomacy: A 
Foreign Policy Illiberal Turn? Journal of Contemporary Asia, 1-21. doi: 10.1080/00472336.2019.1601240

ODI. (2020). China's distant water fishing fleet; Scale, impact and governance. Retrieved November 7, 2020, from ODI: https://www.odi.org/sites/odi.org.uk/files/resource-docu ments/chinesedistantwaterfishing_web_1.pdf

Oegroseno, A. H. (2019, December 17). Quo vadis, global ocean governance? Retrieved November 5, 2020, from The Jakarta Post:https://www.thejakartapost.com/academia/2019 /12/17/quo-vadis-global-ocean-governance.html

Percy, S. (2016). Maritime Crime and Naval Response. Survival, 58(3), 155-186. doi: 10.1080/00396338.2016.1186986

Pudjiastuti, S. (2020, June 12). Tantangan Indonesia untuk Akhiri Praktik Illegal Fishing [Webinar]. Retrieved February, 9, 2021 from Kumparan: https://www.youtube.com/watch?v=1 CwsL7IDUUQ

Purba, K. (2019, September 20). 'Pak' Jokowi: This time you should go to New York! Opinion. Retrieved November 3, 2020, from The Jakarta Post: https://www.thejakarta post.com/academia/2019/09/20/pak-jokowi-this-time-you -should-go-to-new-york.html

Qin, S. (2015, December 3). A Retreat From Multilateralism: Foreign Policy Restructuring Under Jokowi. Retrieved November 7, 2020, from Australia Institute of International Affairs: https://www.internationalaffairs.org.au/australi anoutlook/a-retreat-from-multilateralism-foreign-policy-re structuring-under-jokowi/

Rijal, N. K. (2019). Smart Maritime Diplomacy: Diplomasi Maritim Indonesia Menuju Poros Maritim Dunia. Jurnal Global \& Strategis, 13(1), 63. doi: 10.20473/jgs.13.1.2019.63-78

Scarpello, F. (2020). Susi Versus the rest: The political economy of the fisheries industry in Indonesia during Jokowi's first term. Asian Journal of Political Science, 28(2), 122-141. doi: $10.1080 / 02185377.2020 .1774908$

Stølsvik, G. (2019). The development of the fisheries crime concept and processes to address it in the international arena. Marine Policy, 105, 123-128. doi: 10.1016/j.marpol .2018 .12 .027

Sukma, R. (2014, August 21). Gagasan Poros Maritim. Retrieved March 25, 2020, from Kompas: https://money.kompas.com /read/2014/08/21/080000726/Gagasan.Poros.Maritim

Sutinen, J. G. (2013). Final Report on Indonesian Fisheries Policy (Indonesia Marine and Climate Support Project). Retrieved August 29, 2020, from CRC: https://www.crc.uri.edu/down load/IMC FisheriesPolicyFinal Report01 2013.pdf

Taufika, R. (2020). Latent Securitisation of Illegal, Unreported and Unregulated (IUU) Fishing in Indonesia. Global: Jurnal Politik Internasional, 22(1), 26. doi: 10.7454/global .v22i1.488

Telesetsky, A. (2014). Laundering fish in the global undercurrents: Illegal, unreported, and unregulated fishing and transnational organized crime. Ecology $L Q, 41,939$.

Tempo. (2016, June 30). Illegal Fishing, Negara Kehilangan Pajak 209,1 Miliar. Retrieved October 17, 2020, from Koran Tempo: https://koran.tempo.co/read/ekonomi-dan-bisnis /401446/illegal-fishing-negara-kehilangan-pajak-rp -2091-miliar?

Tempo. (2017, July 11). Susi Pudjiastuti Klaim Satgas 115 Berhasil Pangkas Pencurian Ikan. Retrieved October 17,
2020, from Tempo: https://bisnis.tempo.co/read/890407/su si-pudjiastuti-klaim-satgas-115-berhasil-pangkas-pencuri an-ikan

The Guardian. (2016, March 11). Five jailed in seafood slavery case. Retrieved October 28, 2020, from The Guardian: https://www.theguardian.com/world/2016/mar/11/sea food-slave-drivers-given

UN Ocean Conference. (2020). Indonesia Leads the Establishment of a Regional Cooperation to Combat Crimes in Fisheries Sector. Retrieved October 28, 2020, from UN Ocean Conference: https://oceanconference.un.org/commitments $/ ? \mathrm{id}=15127$

United Nations Convention against Transnational Organized Crime, September 29, 2003, https://www.unodc.org/unodc/en/or ganized-crime/intro/UNTOC.html\#Fulltext

Weigold, A. (2015, July 17). The Future of IORA: Jakarta to Take the Lead. Retrieved October 17, 2020, from Future Direction International: https://www.futuredirections.org.au/publica tion/the-future-of-iora-jakarta-to-take-the-lead/

Wirajuda, H. (2009). Pernyataan Pers Tahunan Menteri Luar Negeri. Retrieved October 28, 2020, from Kementerian Luar Negeri Rl: https://kemlu.go.id/portal/id/read/736/pidato/per nyataan-pers-tahunan-menteri-luar-negeri-ri-tahun-2009 